\title{
MATHEMATICAL MODELING OF STEAM METHANE REFORMING PROCESS
}

\author{
ŞTEFAN CRISTIAN GALUSNYAK ${ }^{a}$, SIMION DRĂGAN ${ }^{a *}$
}

\begin{abstract}
This article presents the mathematical model of mass balance, the mathematical model at equilibrium for steam methane reforming process and the analysis of the equilibrium model for different operating conditions $\left(T, P, X_{\text {feed }}\right)$. The optimal operating conditions were established based on the analysis of the equilibrium model. It was also developed the mathematical model of heat balance, while the optimal size of catalyst granules was determined. The optimal working conditions were set by the equilibrium process' analysis, the reactor feed ratio, $\mathrm{H}_{2} \mathrm{O}: \mathrm{CH}_{4}, 3: 1$, the temperature in the range of $780-1140 \mathrm{~K}$ and the pressure of about $30 \mathrm{~atm}$.
\end{abstract}

Keywords: steam methane reforming, mathematical modeling, stoichiometric independent reaction, equilibrium process analysis

\section{INTRODUCTION}

During the last years, the demand of crops has increased, thus the production of fertilizers seems to be very suitable for countries with a welldeveloped agriculture. Ammonia is a very important product of chemical industry due to its various uses, both as finite or as intermediate product. According to a study made by Jeenchary and Siemanond [1], about $88 \%$ of the ammonia production is used for the production of fertilizers, synthetic fibers and coolers. Ammonia is obtained through the Haber-Bosch process, where, in most cases, the source of hydrogen is the natural gas while the nitrogen is taken from the air. The overall energy consumption for ammonia process is somewhere around $1.1^{*} 10^{12} \mathrm{~kJ} / \mathrm{hr}$. This process consumes $1 \%$ of annual energy production and generates over $3 \%$ of the total greenhouse gases [1]. Given the high thermal input needed, even the slightest improvement would translate into major benefits, both from an economic standpoint, as well as regarding environmental issues.

\footnotetext{
a Babes-Bolyai University, Faculty of Chemstry and Chemical Engineering, 11 Arany Janos str., RO-400028, Cluj-Napoca, Romania

*Corresponding author: sdragan@chem.ubbcluj.ro
} 
Numerous researches are currently being carried out to find new, more economical and cleaner sources, such as obtaining hydrogen through the water electrolysis process using renewable energy (solar or wind power). From the environmental point of view, water electrolysis has been proved to be one of the most propitious alternatives in the production of hydrogen, as long as the power sources are renewable $[2,3]$. Nevertheless, the results show that the hydrogen source in the synthesis of ammonia will remain, at least in the upcoming decades, the natural gas.

The European Commission foresees an increase in the amount of world's hydrogen production. That will come as a consequence of the costs reduction in hydrogen technologies as well as an increased demand of hydrogen in the transport sector [4]. Uyar and Besiki [5] mention that hydrogen could meet $18 \%$ of the total energy demand, reduce, at the same time, about $6 \mathrm{Gt}$ of carbon dioxide emissions annually. As presented by Pashchenko [6], steam reforming of hydrocarbons represents the leading route for producing hydrogen and syngas. Ewan and Allen [7] point out that $96 \%$ of the hydrogen produced has fossil fuels as raw materials, while Calisan et al [8], show that approximately $50 \%$ of the world's hydrogen production is achieved by the steam methane reforming process despite the fact that different other production routes are well developed and well known.

The methane reforming reaction takes place between $800^{\circ} \mathrm{C}$ $1000^{\circ} \mathrm{C}$, in the presence of catalysts, and in a pressure range of $20-30 \mathrm{bar}$, according to Nielsen [9].

Acknowledging aforementioned problems concerning the environment, we employed the values mentioned above for the physical parameters in modeling and optimizing the steam methane reforming process.

\section{RESULTS AND DISCUSSION}

\section{Mathematical model of mass balance}

The characteristic equation for the steam methane reforming process is presented below [10]:

$\left[\mathrm{CH}_{4}+\mathrm{H}_{2} \mathrm{O}+\mathrm{A}^{\prime \prime}\right]_{\mathrm{g}}+[\mathrm{K}]_{\mathrm{s}}=\left[\mathrm{H}_{2}+\mathrm{CO}_{2}+\mathrm{CO}+\mathrm{CH}_{4}+\mathrm{A}\right]_{\mathrm{g}}+[\mathrm{K}]_{\mathrm{s}}$, where $A$ " represents the inert and $\mathrm{K}$ the catalyst.

Using the Graham-Schmidt algebraic method we established how many and which of the four possible reactions are stoichiometric independent.

The possible reactions for this process are:

$$
\begin{aligned}
& \mathrm{CH}_{4}+\mathrm{H}_{2} \mathrm{O} \rightleftharpoons \mathrm{CO}+3 \mathrm{H}_{2} \\
& \mathrm{CO}+\mathrm{H}_{2} \mathrm{O} \rightleftharpoons \mathrm{CO}_{2}+\mathrm{H}_{2} \\
& \mathrm{CH}_{4}+2 \mathrm{H}_{2} \mathrm{O} \rightleftharpoons \mathrm{CO}_{2}+4 \mathrm{H}_{2} \\
& \mathrm{CH}_{4}+\mathrm{CO}_{2} \rightleftharpoons 2 \mathrm{CO}+2 \mathrm{H}_{2}
\end{aligned}
$$


Stoichiometric independent are those reactions for which the condition presented below is fulfilled:

$$
A_{\mathrm{Ri}}^{\mathrm{T}} \cdot \mathrm{A}_{\mathrm{e}}=0
$$

where $A_{R i}^{T}$ represents the transposed matrix of the considered reaction and $A_{e}$ represents the matrix of the elements.

For the reactions of our process, we obtain:

$$
\begin{aligned}
& A_{R 1}^{T} \cdot A_{e}=(-1310-1) \cdot A_{e}=0 \\
& A_{R 2}^{T} \cdot A_{e}=(01-11-1) \cdot A_{e}=0 \\
& A_{R 3}^{T} \cdot A_{e}=\left(\begin{array}{llll}
-1 & 4 & 0 & 1
\end{array}-2\right) \cdot A_{e}=0 \\
& A_{R 4}^{T} \cdot A_{e}=(-122-10) \cdot A_{e}=0
\end{aligned}
$$

As it can be seen, all four reactions fulfil this condition, thus, in order to find out which reactions are stoichiometric independent we did a thermodynamic analysis. As a result, it was found that R1 and R2 are the only one who satisfy the thermodynamic condition, $\Delta_{R} G<0$.

The methane conversion, for the first reaction, and the carbon monoxide conversion, in the second reaction are defined:

$$
\begin{aligned}
& \eta_{\mathrm{CH}_{4}}=\frac{\mathrm{n}_{\mathrm{CH}_{4}}^{01}-\mathrm{n}_{\mathrm{CH}_{4}}^{1}}{n_{\mathrm{CH}_{4}}^{01}}=\frac{\mathrm{n}_{\mathrm{H}_{2} 0}^{01}-\mathrm{n}_{\mathrm{H}_{2} \mathrm{O}}^{1}}{\mathrm{n}_{\mathrm{CH}_{4}}^{01}}=\frac{\mathrm{n}_{\mathrm{CO}}^{1}-\mathrm{n}_{\mathrm{CO}}^{01}}{\mathrm{n}_{\mathrm{CH}_{4}}^{01}}=\frac{\mathrm{n}_{\mathrm{H}_{2}}^{1}-\mathrm{n}_{\mathrm{H}_{2}}^{01}}{3 \cdot \mathrm{n}_{\mathrm{CH}_{4}}^{01}} \\
& \eta_{\mathrm{CO}}=\frac{n_{\mathrm{CO}}^{02}-n_{\mathrm{CO}}^{2}}{n_{\mathrm{CO}}^{02}}=\frac{n_{\mathrm{H}_{2} \mathrm{O}}^{02}-n_{\mathrm{H}_{2} \mathrm{O}}^{2}}{n_{\mathrm{CO}}^{02}}=\frac{n_{\mathrm{CO}_{2}}^{2}-n_{\mathrm{CO}_{2}}^{02}}{n_{\mathrm{CO}}^{02}}=\frac{n_{\mathrm{H}_{2}}^{2}-n_{\mathrm{H}_{2}}^{02}}{n_{\mathrm{CO}}^{02}}
\end{aligned}
$$

The concretization relations for the two stoichiometric independent reactions are:

$$
\begin{array}{ccccc}
\mathrm{n}_{\mathrm{CH}_{4}}^{01}=\mathrm{n}_{\mathrm{CH}_{4}}^{0} & \mathrm{n}_{\mathrm{CO}}^{02}=\mathrm{n}_{\mathrm{CO}}^{1} & \mathrm{n}_{\mathrm{H}_{2} \mathrm{O}}^{02}=\mathrm{n}_{\mathrm{H}_{2} \mathrm{O}}^{1} & \mathrm{n}_{\mathrm{H}_{2} \mathrm{O}}^{2}=\mathrm{n}_{\mathrm{H}_{2} \mathrm{O}} & \mathrm{n}_{\mathrm{CO}_{2}}^{2}=\mathrm{n}_{\mathrm{CO}_{2}} \\
\mathrm{n}_{\mathrm{H}_{2} \mathrm{O}}^{01}=\mathrm{n}_{\mathrm{H}_{2} \mathrm{O}}^{0} & \mathrm{n}_{\mathrm{H}_{2}}^{02}=\mathrm{n}_{\mathrm{H}_{2}}^{1} & \mathrm{n}_{\mathrm{CH}_{4}}^{1}=\mathrm{n}_{\mathrm{CH}_{4}} & \mathrm{n}_{\mathrm{CO}}^{2}=\mathrm{n}_{\mathrm{CO}} & \mathrm{n}_{\mathrm{H}_{2}}^{2}=\mathrm{n}_{\mathrm{H}_{2}}
\end{array}
$$

Some simplifications were made also for the algebraic mass balance equations described below, the conversion of methane was replaced with $\alpha$, $\eta_{\mathrm{CH}_{4}}=\alpha$, whereas with $\beta$ it is represented the product between the conversion of methane and carbon monoxide $\eta_{\mathrm{CH}_{4}} \cdot \eta_{\mathrm{CO}}=\beta$.

The algebraic mass balance equations expressed in moles and in mole fractions are shown in Table 1 and Table 2. Those expressed in mole fractions (b), are deduced from the first type (a), by replacing the next ratios:

$$
\dot{\mathrm{X}}_{\mathrm{H}_{2} \mathrm{O}}^{0}=\frac{\mathrm{n}_{\mathrm{H}_{2} \mathrm{O}}^{0}}{\mathrm{n}_{\mathrm{CH}_{4}}^{0}} ; \dot{\mathrm{X}}_{\mathrm{CO}_{2}}^{0}=\frac{\mathrm{n}_{\mathrm{CO}_{2}}^{0}}{\mathrm{n}_{\mathrm{CH}_{4}}^{0}} ; \dot{\mathrm{X}}_{\mathrm{H}_{2}}^{0}=\frac{\mathrm{n}_{\mathrm{H}_{2}}^{0}}{\mathrm{n}_{\mathrm{CH}_{4}}^{0}} ; \dot{\mathrm{X}}_{\mathrm{A}^{\prime \prime}}^{0}=\frac{\mathrm{n}_{\mathrm{A}^{\prime \prime}}^{0}}{\mathrm{n}_{\mathrm{CH}_{4}}^{0}}
$$


Table 1. Algebraic mass balance equations expressed in moles

\begin{tabular}{|c|c|c|c|c|}
\hline \multirow{2}{*}{$\begin{array}{l}\text { Crt. } \\
\mathrm{Nr}\end{array}$} & \multirow{2}{*}{ Comp } & \multirow{2}{*}{ IN } & \multicolumn{2}{|c|}{ Form of algebraic mass balance equation } \\
\hline & & & $a$ & $\mathrm{~b}$ \\
\hline 1 & $\mathrm{CH}_{4}$ & $\mathrm{n}_{\mathrm{CH}_{4}}^{0}$ & $\mathrm{n}_{\mathrm{CH}_{4}}=\mathrm{n}_{\mathrm{CH}_{4}}^{0} \cdot\left(1-\eta_{\mathrm{CH}_{4}}\right)$ & $\mathrm{n}_{\mathrm{CH}_{4}}=\mathrm{n}_{\mathrm{CH}_{4}}^{0} \cdot(1-\alpha)$ \\
\hline 2 & $\mathrm{H}_{2} \mathrm{O}$ & $\mathrm{n}_{\mathrm{H}_{2} \mathrm{O}}^{0}$ & $\mathrm{n}_{\mathrm{H}_{2} \mathrm{O}}=\mathrm{n}_{\mathrm{H}_{2} \mathrm{O}}^{0}-\mathrm{n}_{\mathrm{CH}_{4}}^{0} \cdot \eta_{\mathrm{CH}_{4}} \cdot\left(1+\eta_{\mathrm{CO}}\right)$ & $\begin{array}{r}\mathrm{n}_{\mathrm{H}_{2} \mathrm{O}}=\mathrm{n}_{\mathrm{CH}_{4}}^{0} \cdot\left(\dot{\mathrm{X}}_{\mathrm{H}_{2} \mathrm{O}}^{0}-\alpha\right. \\
-\beta)\end{array}$ \\
\hline 3 & $\mathrm{CO}_{2}$ & $\mathrm{n}_{\mathrm{CO}_{2}}^{0}$ & $\mathrm{n}_{\mathrm{CO}_{2}}=\mathrm{n}_{\mathrm{CO}_{2}}^{0}+\mathrm{n}_{\mathrm{CH}_{4}}^{0} \cdot \eta_{\mathrm{CH}_{4}} \cdot \eta_{\mathrm{CO}}$ & $\mathrm{n}_{\mathrm{CO}_{2}}=\mathrm{n}_{\mathrm{CH}_{4}}^{0} \cdot\left(\dot{\mathrm{X}}_{\mathrm{CO}_{2}}^{0}+\beta\right)$ \\
\hline 4 & $\mathrm{CO}$ & $\mathrm{n}_{\mathrm{CO}}^{0}$ & $\mathrm{n}_{\mathrm{CO}}=\mathrm{n}_{\mathrm{CH}_{4}}^{0} \cdot \eta_{\mathrm{CH}_{4}} \cdot\left(1-\eta_{\mathrm{CO}}\right)$ & $\mathrm{n}_{\mathrm{CO}}=\mathrm{n}_{\mathrm{CH}_{4}}^{0} \cdot(\alpha-\beta)$ \\
\hline 5 & $\mathrm{H}_{2}$ & $\mathrm{n}_{\mathrm{H}_{2}}^{0}$ & $\mathrm{n}_{\mathrm{H}_{2}}=\mathrm{n}_{\mathrm{H}_{2}}^{0}+\mathrm{n}_{\mathrm{CH}_{4}}^{0} \cdot \eta_{\mathrm{CH}_{4}} \cdot\left(3+\eta_{\mathrm{CO}}\right)$ & $\begin{array}{r}\mathrm{n}_{\mathrm{H}_{2}}=\mathrm{n}_{\mathrm{CH}_{4}}^{0} \cdot\left(\dot{\mathrm{X}}_{\mathrm{H}_{2}}^{0}+3 \cdot \alpha\right. \\
-\beta)\end{array}$ \\
\hline 6 & A" & $\mathrm{n}_{\mathrm{A} \prime \prime}^{0}$ & $\mathrm{n}_{\mathrm{A}^{\prime \prime}}=\mathrm{n}_{\mathrm{A}^{\prime \prime}}^{0}$ & $\mathrm{n}_{\mathrm{A}^{\prime \prime}}=\mathrm{n}_{\mathrm{CH}_{4}}^{0} \cdot \dot{\mathrm{X}}_{\mathrm{A}^{\prime \prime}}^{0}$ \\
\hline \multicolumn{3}{|c|}{ Total } & $\mathrm{n}_{\mathrm{T}}=\mathrm{n}_{\mathrm{T}}^{0} \cdot\left(1+2 \cdot \mathrm{X}_{\mathrm{CH}_{4}}^{0} \cdot \eta_{\mathrm{CH}_{4}}\right)$ & $\mathrm{n}_{\mathrm{T}}=\mathrm{n}_{\mathrm{CH}_{4}}^{0} \cdot(\mathrm{A}+2 \cdot \alpha)$ \\
\hline
\end{tabular}

Table 2. Algebraic mass balance equations expressed in mole fractions

\begin{tabular}{|c|c|c|c|c|}
\hline \multirow{2}{*}{$\begin{array}{l}\mathrm{Crt} \\
\mathrm{Nr}\end{array}$} & \multirow{2}{*}{ Comp } & \multirow{2}{*}{ IN } & \multicolumn{2}{|c|}{ Form of algebraic mass balance equations } \\
\hline & & & $a$ & $\mathrm{~b}$ \\
\hline 1 & $\mathrm{CH}_{4}$ & $\mathrm{n}_{\mathrm{CH}_{4}}^{0}$ & $\mathrm{X}_{\mathrm{CH}_{4}}=\frac{\mathrm{X}_{\mathrm{CH}_{4}}^{0} \cdot(1-\alpha)}{1+2 \cdot \mathrm{X}_{\mathrm{CH}_{4}}^{0} \cdot \alpha}$ & $\mathrm{X}_{\mathrm{CH}_{4}}=\frac{1-\alpha}{\mathrm{A}+2 \cdot \alpha}$ \\
\hline 2 & $\mathrm{H}_{2} \mathrm{O}$ & $\mathrm{n}_{\mathrm{H}_{2} \mathrm{O}}^{0}$ & $\mathrm{X}_{\mathrm{H}_{2} \mathrm{O}}=\frac{\mathrm{X}_{\mathrm{H}_{2} \mathrm{O}}^{0}-\mathrm{X}_{\mathrm{CH}_{4}}^{0} \cdot \alpha-\mathrm{X}_{\mathrm{CH}_{4}}^{0} \cdot \beta}{1+2 \cdot \mathrm{X}_{\mathrm{CH}_{4}}^{0} \cdot \alpha}$ & $\mathrm{X}_{\mathrm{H}_{2} \mathrm{O}}=\frac{\mathrm{X}_{\mathrm{H}_{2} \mathrm{O}}^{0}-\alpha-\beta}{A+2 \cdot \alpha}$ \\
\hline 3 & $\mathrm{CO}_{2}$ & $\mathrm{n}_{\mathrm{CO}_{2}}^{0}$ & $\mathrm{X}_{\mathrm{CO}_{2}}=\frac{\mathrm{X}_{\mathrm{CO}_{2}}^{0}+\mathrm{X}_{\mathrm{CH}_{4}}^{0} \cdot \beta}{1+2 \cdot \mathrm{X}_{\mathrm{CH}_{4}}^{0} \cdot \alpha}$ & $\mathrm{X}_{\mathrm{CO}_{2}}=\frac{\mathrm{X}_{\mathrm{CO}_{2}}^{0}+\beta}{\mathrm{A}+2 \cdot \alpha}$ \\
\hline 4 & $\mathrm{CO}$ & $\mathrm{n}_{\mathrm{CO}}^{0}$ & $\mathrm{X}_{\mathrm{CO}}=\frac{\mathrm{X}_{\mathrm{CH}_{4}}^{0} \cdot \alpha-\mathrm{X}_{\mathrm{CH}_{4}}^{0} \cdot \beta}{1+2 \cdot \mathrm{X}_{\mathrm{CH}_{4}}^{0} \cdot \alpha}$ & $\mathrm{X}_{\mathrm{CO}}=\frac{\alpha-\beta}{\mathrm{A}+2 \cdot \alpha}$ \\
\hline 5 & $\mathrm{H}_{2}$ & $\mathrm{n}_{\mathrm{H}_{2}}^{0}$ & $\mathrm{X}_{\mathrm{H}_{2}}=\frac{\mathrm{X}_{\mathrm{H}_{2}}^{0}+3 \cdot \mathrm{X}_{\mathrm{CH}_{4}}^{0} \cdot \alpha+\mathrm{X}_{\mathrm{CH}_{4}}^{0} \cdot \beta}{1+2 \cdot \mathrm{X}_{\mathrm{CH}_{4}}^{0} \cdot \alpha}$ & $\mathrm{X}_{\mathrm{H}_{2}}=\frac{\mathrm{X}_{\mathrm{H}_{2}}^{0}+3 \cdot \alpha+\beta}{\mathrm{A}+2 \cdot \alpha}$ \\
\hline 6 & A" & $\mathrm{n}_{\mathrm{A}^{\prime \prime}}^{0}$ & $\mathrm{X}_{\mathrm{A}^{\prime \prime}}=\frac{\mathrm{X}_{\mathrm{A}^{\prime \prime}}^{0}}{1+2 \cdot \mathrm{X}_{\mathrm{CH}_{4}}^{0} \cdot \alpha}$ & $\mathrm{X}_{\mathrm{A}^{\prime \prime}}=\frac{\mathrm{X}_{\mathrm{A}^{\prime \prime}}^{0}}{\mathrm{~A}+2 \cdot \alpha}$ \\
\hline
\end{tabular}

\section{Mathematical model of heat balance}

The oxidation process takes place with an excess of air, thus the oxidation process is complete. The methane's conversion equals 1 .

The characteristic equation for the oxidation process is:

$\left[\mathrm{CH}_{4}+\mathrm{A}^{\prime \prime}\right]_{\mathrm{g}}+\left[\mathrm{O}_{2}+\mathrm{N}_{2}+\mathrm{A} "\right]_{\mathrm{g}}=\left[\mathrm{CO}_{2}+\mathrm{O}_{2}+\mathrm{N}_{2}+\mathrm{H}_{2} \mathrm{O}+\mathrm{A} "\right]_{\mathrm{g}}$

The mathematical model of heat balance is described by two equations. The equation number (8) express the heat needed to take place the reaction, while equation number (9) shows the heat which must be brought from the outside, taking into consideration that the steam methane reforming reaction is an endothermic reaction. 


$$
\begin{array}{r}
\Delta \mathrm{H}_{\text {nec }}=41100 \cdot \alpha-10320 \cdot \beta+(32.5 \cdot \alpha-0.522 \cdot \beta+3.422+ \\
\left.7.219 \cdot \mathrm{X}_{\mathrm{H}_{2} \mathrm{O}}\right) \cdot \mathrm{T}-\left(17.93 \cdot \alpha-4.134 \cdot \beta-8.922-1.87 \cdot \mathrm{X}_{\mathrm{H}_{2} \mathrm{O}}\right) \cdot 10^{-3} \cdot \mathrm{T}^{2}+ \\
\left(2.85 \cdot \alpha-1.336 \cdot \beta-1.388+0.089 \cdot \mathrm{X}_{\mathrm{H}_{2} \mathrm{O}}\right) \cdot 10^{-6} \cdot \mathrm{T}^{3}-(3.422+7.219 \\
\left.\mathrm{X}_{\mathrm{H}_{2} \mathrm{O}}\right) \cdot \mathrm{T}_{0}-\left(8.922-1.187 \cdot \mathrm{X}_{\mathrm{H}_{2} \mathrm{O}}\right) \cdot 10^{-3} \cdot \mathrm{T}_{0}^{2}+\left(1.388-0.089 \cdot \mathrm{X}_{\mathrm{H}_{2} \mathrm{O}}\right) \\
10^{-6} \cdot \mathrm{T}_{0}^{3} \\
\mathrm{Q}_{\mathrm{ex}}=\mathrm{n}_{\mathrm{CH}_{4}}^{0} \cdot \Delta \mathrm{H}_{\mathrm{nec}}
\end{array}
$$

The optimal size of catalyst granules was determined on the basis of the following algorithm:

$$
\begin{aligned}
& \frac{\partial \mathrm{K}_{\mathrm{T}}}{\partial \mathrm{d}}=0 \Rightarrow\left(\frac{\mathrm{d}}{\mathrm{D}}\right)_{\text {optim }} \\
& \mathrm{Nu}=\frac{\mathrm{K}_{\mathrm{T}} \times \mathrm{D}}{\lambda}=0.542 \times \mathrm{Re}^{0,93} \times \mathrm{e}^{\frac{-6 \times \mathrm{d}}{\mathrm{D}}} \\
& \frac{\mathrm{K}_{\mathrm{T}} \times \mathrm{D}}{\lambda}=0.542 \times\left(\frac{\rho \times \mathrm{w}_{0} \times \mathrm{d}}{\eta}\right)^{0.93} \times \mathrm{d}^{0.93} \times \mathrm{e}^{\frac{-6 \times \mathrm{d}}{\mathrm{D}}} \\
& \left(\frac{d}{D}\right)_{\text {optim }}=0.155
\end{aligned}
$$

\section{Kinetic model of steam methane reforming process}

The basic structural diagram for the transport and transfer process is depicted in Figure 1.

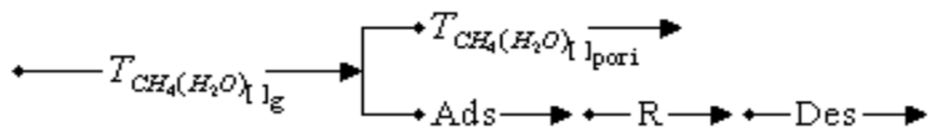

Figure 1. Schematic overview of the mass transport and transfer process

By comparing the rate of the processes showed in the above scheme, there are three possible macro-kinetic mechanisms:

> Macro-kinetic mechanism of transfer through the gaseous phase defined by the equation obtained by integrating the steady-state one:

$$
\mathrm{n}_{\mathrm{AK}}=\frac{4 \times \mathrm{D}}{\mathrm{r}} \times \int_{\mathrm{C}_{\mathrm{AK}}^{0}}^{\mathrm{c}_{\mathrm{AK}}}-\overline{\mathrm{r}} \times \mathrm{dC}_{\mathrm{AK}} \times \mathrm{r}^{2} \times \pi
$$

> Macro-kinetic model of transformation which is described by the following equation:

$$
\frac{d \eta}{d \tau_{c}}=K^{(1)} \times \frac{C_{A 1}^{0} \times(1-\eta)}{(1+\alpha \times \eta)} \times\left(\frac{\eta}{1+\alpha \times \eta} \times \frac{\eta^{e}}{1+\alpha \times \eta^{e}}\right)
$$

> Combined transfer and transport process described through a more complex equation which was not taken into consideration

It has been shown that at an industrial level, mass transport and transfer reaches equilibrium, and the steam methane reforming process, as a whole, is most accurately described by a macro-kinetic model of heat transfer from the reactor's surface towards the reaction mixture [10]. 


\section{Mathematical model of the equilibrium process}

Steam methane reforming is a contact process, therefore, the equilibrium is described through chemical equilibrium [11]. The equilibrium constants for the stoichiometric independent reactions are defined with respect to the partial pressure of each component:

$$
\begin{aligned}
\mathrm{K}_{\mathrm{p} 1} & =\frac{\mathrm{p}_{\mathrm{CO}} \cdot \mathrm{p}_{\mathrm{H}_{2}}^{3}}{\mathrm{p}_{\mathrm{CH}_{4} \cdot \mathrm{p}_{\mathrm{H}_{2} \mathrm{O}} \mathrm{O}}} \\
\mathrm{K}_{\mathrm{p} 2} & =\frac{\mathrm{p}_{\mathrm{CO}_{2}} \cdot \mathrm{p}_{\mathrm{H}_{2}}}{\mathrm{p}_{\mathrm{CO}} \cdot \mathrm{p}_{\mathrm{H}_{2} \mathrm{O}}}
\end{aligned}
$$

The partial pressure of each component was substituted according to Dalton's law with the total pressure and his concentration in the reaction mixture. This leads to the following relations:

$$
\begin{aligned}
\mathrm{K}_{\mathrm{p} 1} & =\frac{\mathrm{x}_{\mathrm{CO}} \cdot \mathrm{x}_{\mathrm{H}_{2}}^{3}}{\mathrm{x}_{\mathrm{CH}_{4}} \cdot \mathrm{x}_{\mathrm{H}_{2} \mathrm{O}}} \cdot \mathrm{P}^{2} \\
\mathrm{~K}_{\mathrm{p} 2} & =\frac{\mathrm{x}_{\mathrm{CO}_{2}} \cdot \mathrm{x}_{\mathrm{H}_{2}}}{\mathrm{x}_{\mathrm{CO}} \cdot \mathrm{x}_{\mathrm{H}_{2} \mathrm{O}}}
\end{aligned}
$$

Using the mathematical model of mass balance, the final relations for the equilibrium constants are:

$$
\begin{gathered}
\mathrm{K}_{\mathrm{p} 1}=\frac{(\alpha-\beta) \cdot(3 \cdot \alpha+\beta)^{3} \cdot \mathrm{P}^{2}}{\left(\mathrm{x}_{\mathrm{H}_{2} \mathrm{O}}^{0}-\alpha-\beta\right) \times(1-\alpha) \cdot\left(1+\mathrm{X}_{\mathrm{H}_{2} \mathrm{O}}^{0}+2 \cdot \alpha\right)^{2}} \\
\mathrm{~K}_{\mathrm{p} 2}=\frac{\beta \cdot(3 \cdot \alpha+\beta)}{(\alpha-\beta) \cdot\left(\mathrm{X}_{\mathrm{H}_{2} \mathrm{O}}^{0}-\alpha-\beta\right)} \\
\lg \mathrm{K}_{\mathrm{p} 1}=\frac{-9861.11}{\mathrm{~T}}-11.87-2.05 \cdot 10^{-3} \cdot \mathrm{T}+0.1779 \cdot 10^{-6} \cdot \mathrm{T}^{2}+8.3432 \cdot \lg \mathrm{T} \\
\lg \mathrm{K}_{\mathrm{p} 2}=\frac{2217.18}{\mathrm{~T}}-3.27467+0.3524 \cdot 10^{-3} \cdot \mathrm{T}-0.0 .507 \cdot 10^{-6} \cdot \mathrm{T}^{2}+0.2969 \\
\lg \mathrm{T}
\end{gathered}
$$

These two relations, (21) and (22), which describe how the equilibrium constants depend on the conversion of methane and carbon monoxide, together with the computational expressions, (23) and (24), which allows us to see the variation of the equilibrium constants with temperature, constitute the mathematical model of the equilibrium process.

Solving these equations will help us to better understand how the conversion, for both components, vary with respect to pressure, temperature and feed ration. All the thermodynamic computations which are needed for describing the process were made using MatLab.

Table 3 presents the values of the enthalpy [cal $/ \mathrm{mol}$ ], entropy [cal $/ \mathrm{mol} \cdot \mathrm{K}$ ] and free Gibbs energy [cal/mol] for the two stoichiometric independent reactions. 
Table 3. Variation of the thermodynamic parameters with respect to temperature for both stoichiometric independent reactions

\begin{tabular}{|c|c|c|c|c|c|c|}
\hline \multirow{2}{T}{$\begin{array}{c}\mathrm{T} \\
{[\mathrm{K}]}\end{array}$} & \multicolumn{3}{|c|}{$\mathrm{R} 1$} & \multicolumn{3}{c|}{$\mathrm{R} 2$} \\
\cline { 2 - 7 } & $\Delta_{\mathrm{R}} \mathrm{H}_{\mathrm{T}}$ & $\Delta_{\mathrm{R}} \mathrm{S}_{\mathrm{T}}$ & $\Delta_{\mathrm{R}} \mathrm{G}_{\mathrm{T}}$ & $\Delta_{\mathrm{R}} \mathrm{H}_{\mathrm{T}}$ & $\Delta_{\mathrm{R}} \mathrm{S}_{\mathrm{T}}$ & $\Delta_{\mathrm{R}} \mathrm{G}_{\mathrm{T}}$ \\
\hline 780 & 53093.95 & 59.46 & 6710.34 & -8922.69 & -8.36 & -2397.32 \\
\hline 820 & 53278.92 & 59.69 & 4326.95 & -8831.17 & -8.25 & -2064.99 \\
\hline 860 & 53446.53 & 59.89 & 1934.96 & -8738.11 & -8.14 & -1737.16 \\
\hline 900 & 53597.40 & 60.06 & -464.44 & -8643.68 & -8.03 & -1413.69 \\
\hline 940 & 53732.21 & 60.21 & -2870.20 & -8548.07 & -7.92 & -1094.45 \\
\hline 980 & 53851.40 & 60.33 & -5281.37 & -8451.14 & -7.82 & -779.30 \\
\hline 1020 & 53955.79 & 60.44 & -7697.10 & -8353.96 & -7.73 & -468.11 \\
\hline 1060 & 54045.93 & 60.53 & -10116.65 & -8255.89 & -7.63 & -160.76 \\
\hline 1100 & 54122.44 & 60.60 & -12539.35 & -8157.20 & -7.54 & 142.87 \\
\hline 1140 & 54185.96 & 60.65 & -14964.59 & -8058.27 & -7.45 & 442.91 \\
\hline
\end{tabular}

Two methods were used in order to compute the values for the equilibrium constants. First method, I, uses the computational relations discussed before, (23) and (24), while the second one, II, uses Van't Hoff's equation, (25).

$$
\ln K_{p}=-\frac{\Delta_{R} G_{T}^{0}}{R \cdot T}
$$

Using the methods described before, we computed the values for the equilibrium constants as presented in Table 4 . The values obtained by both methods, for both equilibrium constants, do not differ by more than $0.44 \%$.

Table 4. The dependence of the equilibrium constants with temperature.

\begin{tabular}{|c|c|c|c|c|}
\hline \multirow{2}{*}{$\begin{array}{c}\mathrm{T} \\
{[\mathrm{K}]}\end{array}$} & \multicolumn{2}{|c|}{$\mathrm{K}_{\mathrm{p} 1}$} & \multicolumn{2}{c|}{$\mathrm{K}_{\mathrm{p} 2}$} \\
\cline { 2 - 5 } & $\mathrm{I}$ & $\mathrm{II}$ & $\mathrm{I}$ & $\mathrm{II}$ \\
\hline 780 & 0.0132 & 0.0132 & 4.6834 & 4.6984 \\
\hline 820 & 0.0702 & 0.0705 & 3.5416 & 3.5531 \\
\hline 860 & 0.3218 & 0.3234 & 2.7559 & 2.7651 \\
\hline 900 & 1.2946 & 1.3009 & 2.1982 & 2.2057 \\
\hline 940 & 4.4618 & 4.664 & 1.7915 & 1.7977 \\
\hline 980 & 15.0374 & 15.1087 & 1.4877 & 1.4929 \\
\hline 1020 & 44.5253 & 44.7339 & 1.2560 & 1.2605 \\
\hline 1060 & 121.6893 & 122.2517 & 1.0760 & 1.0799 \\
\hline 1100 & 309.5796 & 310.9887 & 0.9338 & 0.9373 \\
\hline 1140 & 738.4565 & 741.7662 & 0.8197 & 0.8229 \\
\hline
\end{tabular}

To prove that the steam methane reforming process is indeed described by the chemical equilibrium, Figure 2 reveal the correspondence between the 
equilibrium constant for the first reaction, steam methane reforming, expressed as activity, and temperature for different constant pressure values. It can be seen that the value of the constant is somewhere around one.

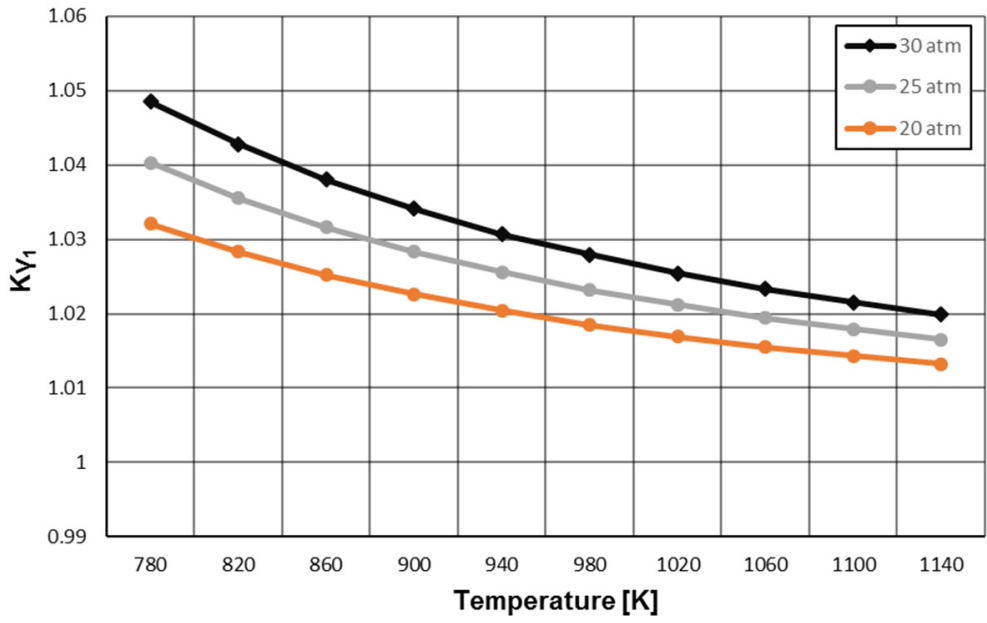

Figure 2. Variation of the first equilibrium constant with the temperature for different constant pressure values

The same is happening for the second reaction. Figure 3 shows that the equilibrium constant, for the water gas shift reaction, has values in the range of $1.01-1.04$ which can be approximate to 1 .

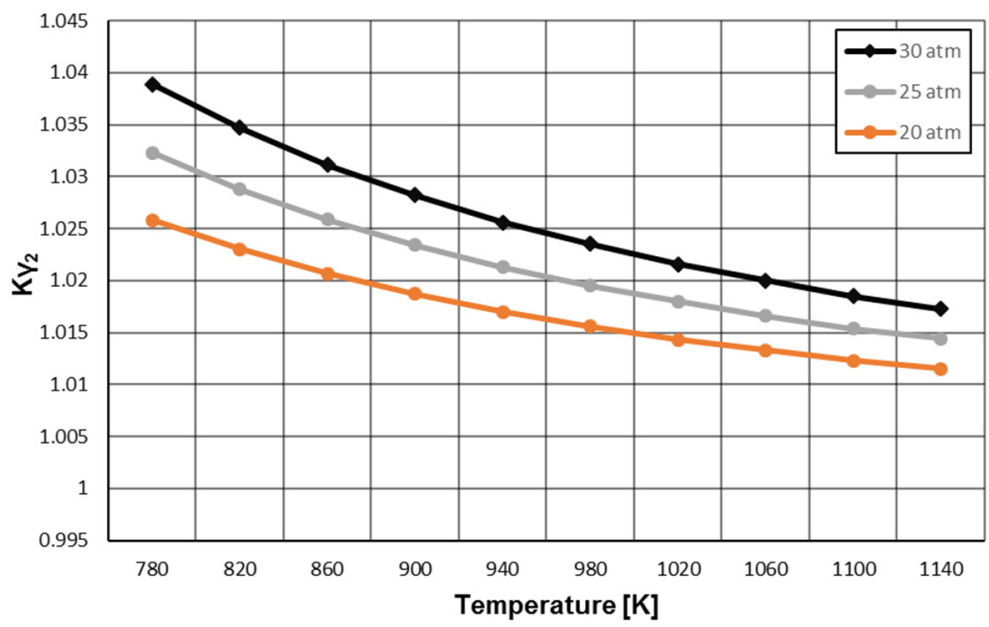

Figure 3. Variation of the second equilibrium constant with the temperature for different constant pressure values 
The mathematical model was developed and solved using MatLab with the purpose of determining the values of $\alpha$ and $\beta$ for different operating conditions: pressure, temperature and feed ratio. The pressures taken into consideration were $10,20,25,30,35,40$ and $50 \mathrm{~atm}$, while the feed ratio has the following values:3, 3.5, 4,5 and 6 . The temperature domain was set between 780 and $1140 \mathrm{~K}$.

The results are represented by the graphics below and explained in the next paragraph.

Figure 4 shows that the conversion of methane is increasing with the increase in temperature and feed ratio. It can be noted that the temperature has a stronger influence than the feed ratio. Thereby, increasing the temperature from 810 up to $1110 \mathrm{~K}$ will cause an increase of about 4.5 times in methane conversion, while an increase in feed ratio determines an increase in methane conversion only of about 1.1 times.

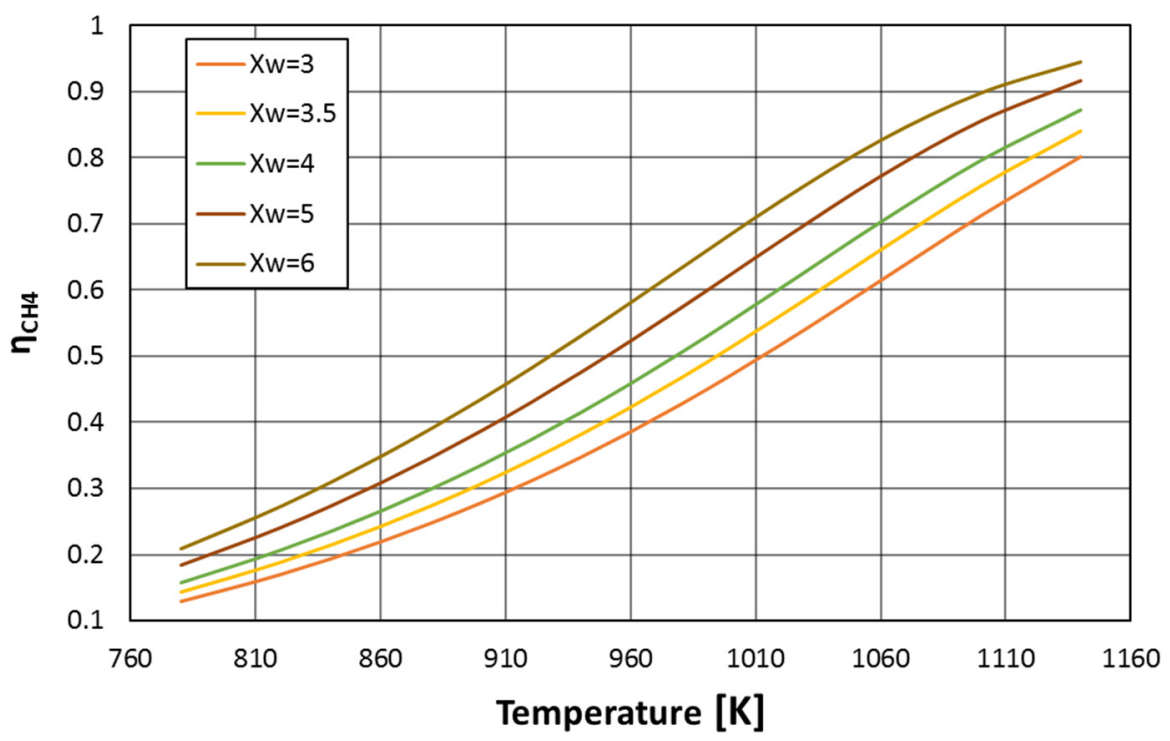

Figure 4. Variation of the conversion for methane with the temperature at constant pressure, $\mathrm{P}=30 \mathrm{~atm}$

In the case of carbon monoxide, Figure 5 , we can see exactly the opposite. The conversion of carbon monoxide decreases with the increase in both, feed ratio and temperature. 


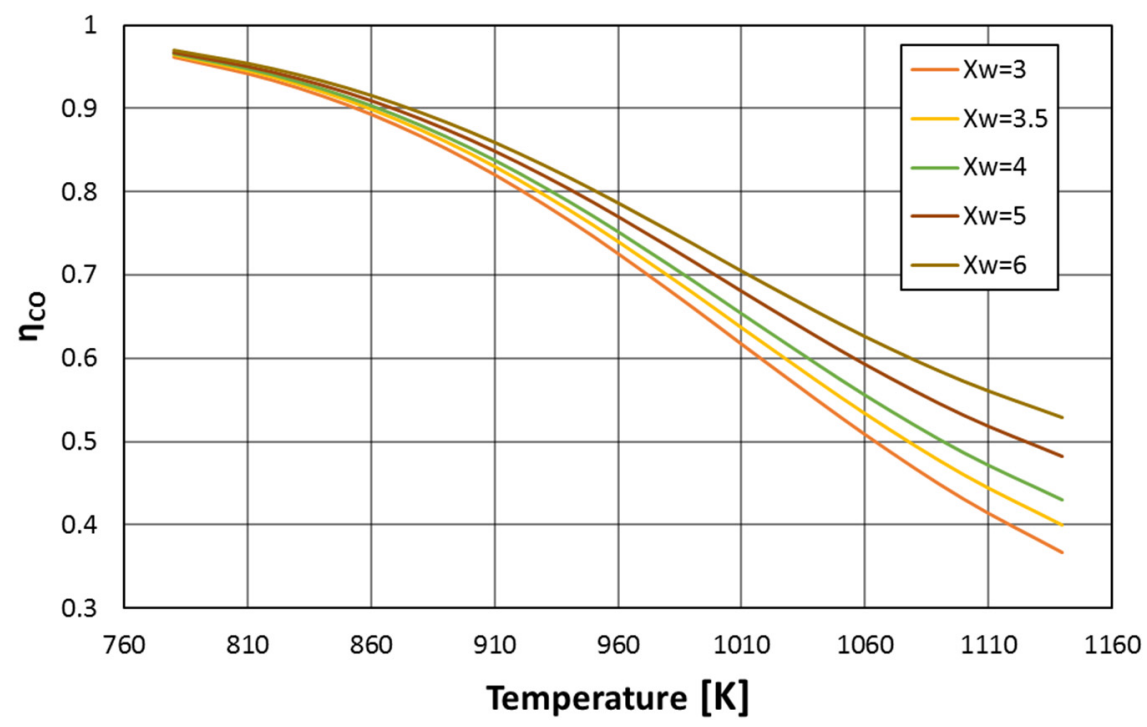

Figure 5. Variation of the conversion for carbon monoxide with respect to temperature at constant pressure, $\mathrm{P}=30 \mathrm{~atm}$

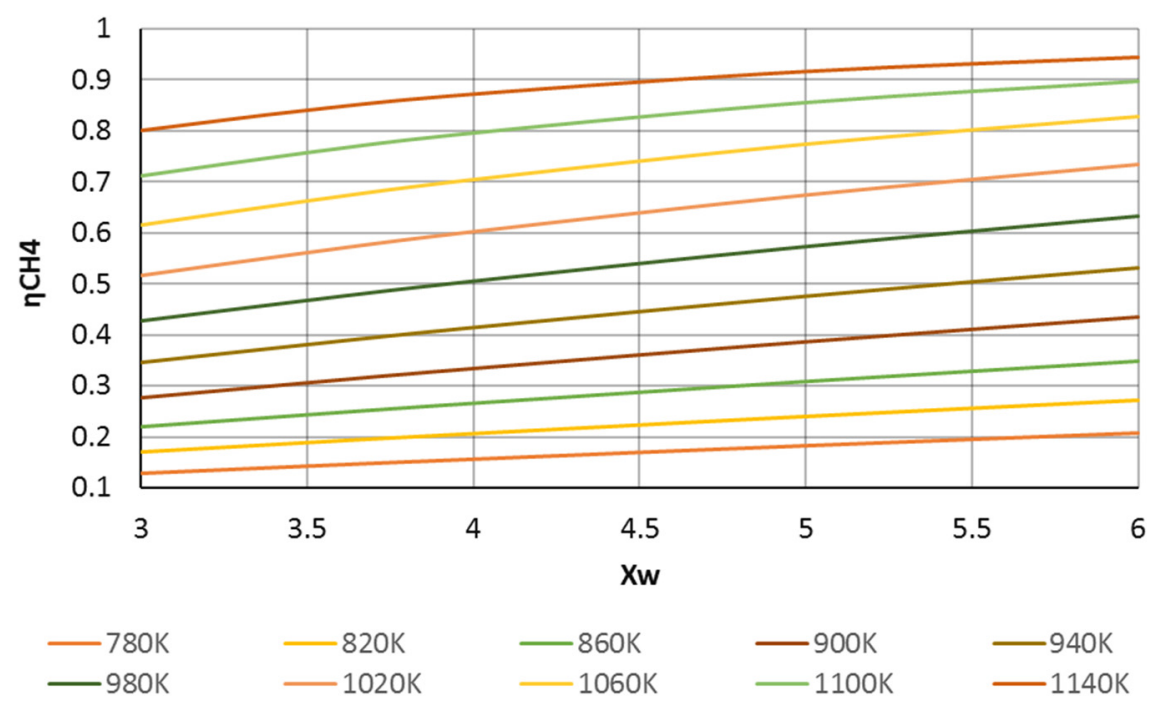

Figure 6. Variation of the conversion for methane with different feed ratios and temperatures, at constant pressure, $\mathrm{P}=30 \mathrm{~atm}$ 
Figure 6 reveals that at 30 atmospheres, the conversion of methane is strongly increasing with the increase in temperature and slowly increases with an increase in the feed ratio.

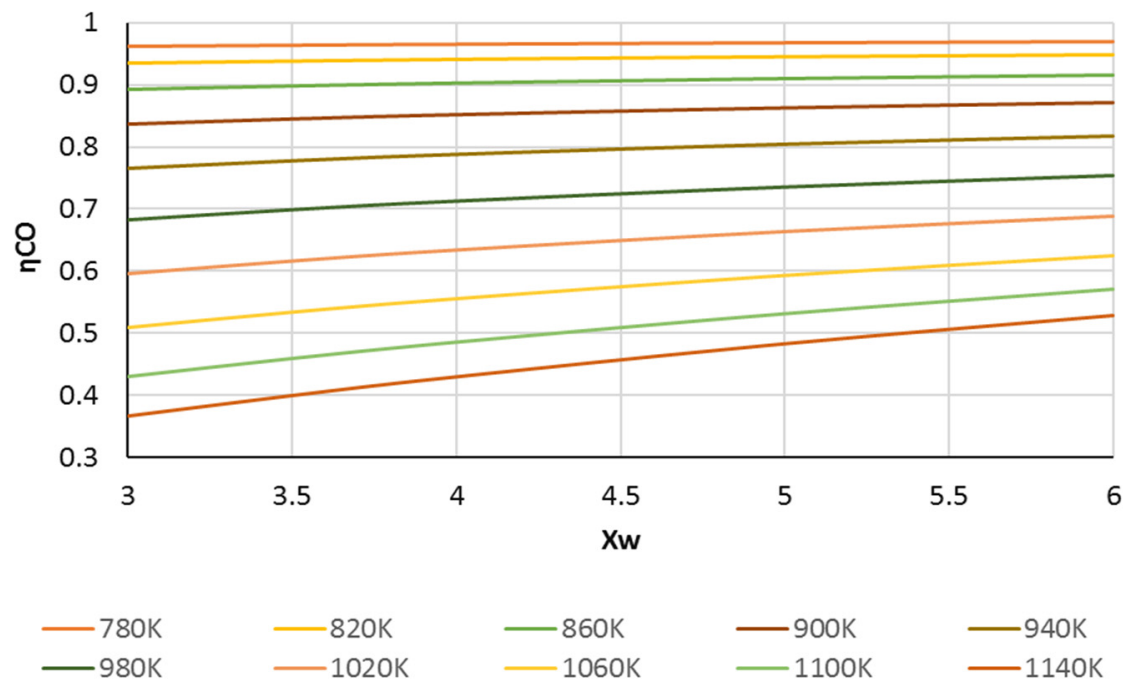

Figure 7. Variation of the conversion for carbon monoxide with different feed ratios and temperatures, at constant pressure, $\mathrm{P}=30 \mathrm{~atm}$

On the other hand, from Figure 7 we can denote that at the same pressure, 30 atmospheres, the conversion of carbon monoxide is decreasing with an increase in temperature and it remains almost constant with an increase in the feed ratio.

\section{CONCLUSIONS}

In this paper there were established based on the characteristic equation the stoichiometric independent reactions for the steam methane reforming process using the algebraic Graham-Schmidt method and thermodynamic analysis.

It was elaborated the mathematical model of mass balance, both in primary form, and also the mathematical model of the equilibrium process.

Solving the equilibrium mathematical model for different operating conditions, temperature, pressures and feed ratios, we found the optimal working conditions. Based on the analysis of the model results, optimal pressure would be 30 atmospheres, feed ratio equal with 3 and the temperature range between $780-1140 \mathrm{~K}$. 
At a production capacity of 1200 tons of ammonia per day, for a pressure of $30 \mathrm{~atm}$ and a feed ratio equal with 3 , the value obtained for the length of the reforming reactor, $10.00 \mathrm{~m}$, is in good accordance with the length of the reforming reactor used by S.C. Ameropa AZOMURES, where for the same working conditions the reforming reactor is $10.33 \mathrm{~m}$ long.

The developed model can be used to simulate and study the reforming process of methane for many other different operating conditions.

\section{REFERENCES}

1. J. Jeenchary; K. Siemanond; Comput.-Aided Chem. Eng., 2018, 43, 385-390.

2. A. Sánchez; M. Martin; J. Cleaner Prod., 2018, 178, 325-342.

3. S. Giddey; S.P.S. Badwal; A. Kulkarni; Int. J. Hydrogen Energy, 2013, 38, 1457614594.

4. A. Soria; L. Szabo; P. Russ; W. Suwala; I. Hidalgo; A. Purwanto; World energy technology outlook 2050, European Commission, 2006.

5. T.S. Uyar; D. Beşikci; Int. J. Hydrogen Energy, 2017, 42, 2453-2456.

6. D. Pashchenko; Fuel, 2019, 236, 686-694.

7. B.C.R. Ewan; R.W.K. Allen; Int. J. Hydrogen Energy, 2005, 30, 809-819.

8. A. Calisan; C.G. Ogulgonen; A. Yilmaz; D. Uner; S. Kinkal; Int. J. Hydrogen Energy, 2019: https://doi.org/10.1016/j.ijhydene.2019.04.033

9. J.R. Rostrup-Nielsen; T. Rostrup-Nielsen; CATTECH, 2002, 6, 150-159.

10. C. Calistru; C. Leonte; I. Siminiceanu; C. Hagiu; O. Popa; Tehnologia îngrăşămintelor minerale, Vol I; Ed. Tehnică Bucureşti: România, 1984; pp. 105-148.

11. S. Drăgan; Elemente de ingineria proceselor chimice; Ed. UBB Cluj-Napoca; România, 2004, pp. 40-44. 